Erratum

\title{
Growth responses of tropical cladocerans to seston from Lake Monte Alegre (Brazil) supplemented with phosphorus, fatty acids, a green algae and a cyanobacterium ${ }^{\text {th }}$
}

\author{
A. da Silva Ferrão-Filho \& M.S. Arcifa
}

\section{Hydrobiologia (2006) DOI 10.1007/s10750-005-0001-3}

The following corrections must be made in this article:

Page 2, right-hand column, paragraph 2, line 2: the reference should be Ferrão-Filho et al. (2003a).
Page 5: The correct Table 3 is given below.

Page 7: The correct Table 4 is given below.

Page 8, left-hand column, paragraph 1, last line: replace 'Table 1' by 'Table 2'.

The publishers apologise for these errors.

Table 3. Results of the general ANOVA for the growth bioassay in summer

\begin{tabular}{llllllll}
\hline \multirow{2}{*}{ Species } & \multicolumn{2}{l}{ Treatments } & & df & $F$ & $p$ \\
\cline { 2 - 5 } & Seston & $+\mathrm{PO}_{4}$ & + PUFA & + Sce & & & \\
\hline C. richardi & $0.183 \pm 0.018(\mathrm{a})$ & $0.185 \pm 0.006(\mathrm{a})$ & $0.146 \pm 0.017(\mathrm{a})$ & $0.269 \pm 0.011(\mathrm{~b})$ & 3.8 & 14.3 & 0.0014 \\
D. gessneri & $0.293 \pm 0.017$ (a) & $0.255 \pm 0.009(\mathrm{a})$ & $0.342 \pm 0.010(\mathrm{ab})$ & $0.377 \pm 0.003(\mathrm{~b})$ & 3.8 & 23.6 & 0.0003 \\
\hline
\end{tabular}

Data are mean growth rates $\left(\mathrm{d}^{-1}\right) \pm \mathrm{SE}$ for both species during the four days of experiment. There were three replicate bottles per treatment, which included: (1) seston; (2) seston $+\mathrm{PO}_{4}$; (3) seston + PUFA and (4) seston + Scenedesmus. In the addition treatments, $3.0 \mu \mathrm{mol} \mathrm{P} 1^{-1}, 0.3 \mathrm{mg} \mathrm{C}^{-1}$ of PUFA-rich fish oil emulsions, and $0.5 \mathrm{mg} \mathrm{C}^{-1}$ of green alga were added to seston. df are the degrees of freedom for the treatments and error. Treatments with same letters are not significantly different (post hoc Tukey test, $p<0.05)$.

Table 4. Results of the general ANOVA for the growth bioassay in autumn

\begin{tabular}{|c|c|c|c|c|c|c|c|}
\hline \multirow[t]{2}{*}{ Species } & \multicolumn{4}{|l|}{ Treatments } & \multirow[t]{2}{*}{$\mathrm{df}$} & \multirow[t]{2}{*}{$F$} & \multirow[t]{2}{*}{$p$} \\
\hline & Seston & $+\mathrm{PO}_{4}$ & $+S y n$ & + Sce & & & \\
\hline C. richardi & $0.313 \pm 0.031(\mathrm{a})$ & $0.421 \pm 0.030(\mathrm{ab})$ & $0.520 \pm 0.027(b)$ & $0.683 \pm 0.040(\mathrm{c})$ & 3.8 & 23.1 & 0.0003 \\
\hline D. ambigua & $0.085 \pm 0.024(\mathrm{a})$ & $0.163 \pm 0.018(\mathrm{a})$ & $0.326 \pm 0.008(\mathrm{~b})$ & $\dagger$ & 2.6 & 46.3 & 0.0002 \\
\hline D. gessneri & $0.084 \pm 0.037(\mathrm{a})$ & $0.288 \pm 0.012(b)$ & $0.413 \pm 0.019(\mathrm{c})$ & $0.461 \pm 0.007(\mathrm{c})$ & 3.8 & 59.1 & $<0.0001$ \\
\hline M. micrura & $0.334 \pm 0.035(\mathrm{a})$ & $0.407 \pm 0.018(\mathrm{a})$ & $0.932 \pm 0.004(b)$ & $1.017 \pm 0.028(\mathrm{~b})$ & 3.8 & 214.3 & $<0.0001$ \\
\hline
\end{tabular}

Data are mean growth rates $\left(\mathrm{d}^{-1}\right) \pm \mathrm{SE}$ during the first two days of the experiment for C. richardi and $M$. micrura, and during four days for D. ambigua and D. gessneri. There were three replicate bottles per treatment, which included: (1) seston; (2) seston $+\mathrm{PO}_{4}$; (3) seston + Synecochoccus and (4) seston + Scenedesmus. In the addition treatments, $3.0 \mu \mathrm{mol} \mathrm{P}{ }^{-1}, 0.5 \mathrm{mg} \mathrm{C}^{-1}$ of cyanobacterium, and $0.5 \mathrm{mg} \mathrm{C}^{-1}$ of green alga were added to seston. df are the degrees of freedom for the treatments and error. Treatments with same letters are not significantly different (Tukey test, $p<0.05$ ). ${ }^{\dagger}$ Not performed due to lack of animals.

\footnotetext{
The online version of the original article can be found at http://dx.doi.org/10.1007/s10750-005-0001-3
} 